\title{
Impact Of The Internet On Internal Service Quality Factors: The Travel Industry Case
}

Shohreh A. Kaynama, (E-mail: skaynama@towson.edu), Towson University Christine I. Black, (E-mail: ciblack@towson.edu), Towson University

Garland Keesling, (E-mail: gkeesling@towson.edu), Towson University

\begin{abstract}
The growth of multichannel and pure-play companies attests to the changes that technology has brought to business processes. These changes have an effect on the quality of service delivery and customer satisfaction. In this qualitative study, the Service Quality Model was applied to gain insight into the internal service quality factors of two types of travel agencies. In addition, the impact of the Internet on quality of service was explored. The findings have theoretical and managerial implications.
\end{abstract}

\section{Introduction}

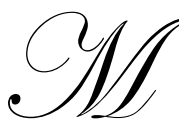

anagers need a framework to conceptualize factors, both internal and external to their firms' operations, which impact service quality as companies venture into providing services online. The reason businesses continue to find the study of service quality relevant is the belief that improvements in service quality will positively impact their bottom line. While there may not be a general connection between quality, price and cost, as this relationship is unique to various situations (Gummesson, 1995), other connections between service quality and factors influencing profitability have been documented. One finding is that improvements in service quality can increase customers' favorable behavioral intentions(Zeithaml, Berry, \& Parasuraman, 1996). However, in order for these favorable intentions to translate into loyal customers who are proven to positively impact profits, businesses must focus on creating value in the minds of targeted consumers (Reichheld, 1996). Intuitively, customers' desired, adequate and perceived levels of service quality will factor into the perceived benefits component of the value equation. To date, the direct relationship between service quality and profits is shown to be both positive and negative due to additional variables still yet to be determined. Already positive connections between service quality and market share, premium pricing, customer retention and purchase intentions provide a wealth of evidence for companies to continue assessing and improving the quality of their services (Zeithaml, 2000).

Through use of gap analysis as outlined in Parasuraman, Zeithaml and Berry'sService Quality Model and the development of the E-QUAL dimensions, the quality of services provided by brick-and-mortar, multichannel and pureplay firms can be assessed. Intended as a conceptual framework and potentially a diagnostic tool, managers are cautioned not to initiate service quality programs without careful integration into their firms' marketing strategy. Our intention is to illuminate possible quality factors which companies can use to assess their customers' desired, adequate and perceived levels of service in both traditional and online settings. While travel agencies are chosen for this exploratory study, implications exist not only for other service industries, but also the service divisions of retailers, wholesalers and manufacturers.

Readers with comments or questions are encouraged to contact the authors via email. 


\section{Service Quality}

Although quality measures in manufacturing have been emphasized for half a century, translation of the importance of quality measures to the service sector did not gain momentum until the 1980's. For a time, the measurement of service quality remained elusive due to the intangibility of services and the unpredictable nature of customer - employee interactions. In order to provide guidance to firms for improving the quality of their services, Parasuraman, Zeithaml and Berry(1985) developed the Service Quality Model. The Model, consisting of five gaps, provides insight into internal and external factors that influence service quality:

GAP1: Consumer expectation - management perception gap

GAP2: Management perception - service quality specification gap

GAP3: Service quality specifications - service delivery gap

GAP4: Service delivery - external communications gap

GAP5: Expected service - perceived service gap

Gaps 1-4 pertain to service quality factors within the firm's sphere of control, while GAP5 applies to consumers' attitudes towards the service provided. Shortly after the initial Service Quality Model was developed, the SERVQUAL scale was created to assess customers' attitudes towards service quality by measuring the difference between the level of service expected and the level of service customers' perceived to have received (Parasuraman et al., 1988). The scale included 22 items bound within five dimensions:

Tangibles: $\quad$ Physical facilities, equipment, and appearance of personnel

Reliability: $\quad$ Ability to perform the promised service dependably and accurately

Responsiveness: Willingness to help customers and provide prompt service

Assurance: $\quad$ Knowledge and courtesy of employees and their ability to inspire trust and confidence

Empathy: $\quad$ Caring, individualized attention the firm provides its customers

Results from the original study of bank, credit card, appliance repair and telephone service customers indicated high reliabilities and consistency for the scale.

Since its inception, the SERVQUAL instrument has been used in many settings from a business school placement center to hospitals (Carman, 1990; Babakus \& Mangold, 1992). While much of the response to SERVQUAL has been positive, there has been some criticism. One criticism is that the SERVQUAL dimensions may not be broadly applicable to all industries, and therefore may need to be modified for specific service settings (Carman, 1990). Another point is made that the expectations component of SERQUAL may not be necessary to yield relevant findings, and that a solely performance based assessment provides the best measurement of service quality (Cronin Jr. \& Taylor, 1992). In response, Parasuraman, Zeithaml and Berry, ) developed revised SERVQUAL instruments expanding the measurement of consumers' expectations into two parts: desired service levels and adequate service levels, between which is a zone of tolerance. Findings from the 1994 study indicate the SERVQUAL scale possesses both high reliability and validity, with the perceptions-only measure having superior predictive quality and the three-column SERVQUAL scale providing the most diagnostic value. The Service Quality Model and SERVQUAL continue to be relevant in the assessment of service quality as evidenced by their prevalence in the Academy of Marketing Science's recent special session on service quality measurement ).

\section{Service Quality And The Internet}

A natural extension for research in service quality is the development of a service quality model for services distributed through the Internet channel. Despite the recent crash of the Internet sector, business-to-consumer ecommerce spending may exceed $\$ 120$ billion in 2002 and the business-to-business e-commerce market could increase to $\$ 1.3$ trillion by 2003 This dramatic growth can be attributed not only to exciting pure-play (online firms without a physical presence) ventures but also to the transition of brick-and-mortar (traditional firms without an online presence) and pure-play companies into multichannel (firms with both a physical and online presence) enterprises. By adopting a 
multichannel strategy, companies hope to advertise directly to, communicate with and transact business with customers without time and place barriers while at the same time reducing their costs. (Saunders, 2000). Because of these perceived benefits, rapid entrance into the Internet channel will continue and both service businesses and businesses with service components will infuse technology into what were formerly low-tech, high-touch service offerings (Bitner et al., 2000).

Initial assessment of e-business performance focused on Website evaluation criteria and the benefits businesses and consumers could receive by using the Internet channel. Bell and Tang (1998) services asked users to rate business Websites based on criteria such as access to Website, content, structure, and unique features and found that retailers received higher scores than entertainment, financial, information or travel. The factors of site quality, trust and positive affect toward the site have also been shown to impact customers' intentions and loyalty, although the impact of these factors is culturally and product dependent (Lynch, 2001). Keeney. focused on measuring the values customers can enjoy through the Internet channel including maximizing access to information, assuring reliable delivery, assuring security, enhancing comparison shopping, and minimizing personal travel.

In order to better understand the importance of technology in the service environment, Parasuraman \& Grewal (Parasuraman et al., 2000) have developed the Pyramid Model adding the fourth component of technology to the existing three components of (1) company, (2) employees and (3) customers. In an attempt to capture the impact of the four components of the Pyramid Model, Kaynama and Black (2000) proposed a new E-QUAL scale, based on SERVQUAL, as a potential measure of customers' perceptions of online service quality. In addition, the originators of the SERVQUAL are currently working on a framework for e-service quality from the customers' perspective with added dimensions for ease of navigation, flexibility, efficiency, site aesthetics, and price knowledge. While the assessment of GAP5 of the original Service Quality Model is critical for assessing online customers' attitudes, companies must continue to assess factors impacting service quality under their internal control. Wang notes that companies pursuing an online strategy often must reorganize their internal operations in order to succeed in the Internet channel. Likewise, Dedhia (provides guidance to e-businesses in terms of managing internal service quality factors including online strategy, complying with international systems and staffing. However, there still remains a need for a comprehensive model of e-business service quality that can illuminate both internal and external service quality gaps to study industries characterized by competition between brick-and-mortar, multichannel and pure-play firms.

\section{Travel Agency Industry}

The travel agency sector provides an interesting case for the study of service quality across brick-and-mortar, multichannel and pure-play firms precisely because the pure-play model has been so successful in redefining the industry. In fact, online spending on travel reached $\$ 13-\$ 18$ billion in 2000, with projections of spending increasing to $\$ 63$ billion by 2006 (Glab, 2001). The dramatic success of Internet distribution of travel services has forced brick-and-mortar travel agencies to recast themselves as information brokers with expertise guiding customers through complex travel arrangements rather than as mere intermediaries for travel suppliers. Travel agents still have a niche in the industry as customers' indicate that poor usability of travel Websites, lack of travel industry knowledge and the considerable amount of time required to book itineraries are all obstacles in purchasing from online travel agencies and suppliers 2000). However, agents should be concerned as some of their best customers may be lured by the Internet as those using the Internet as a source of travel information tend to be college-educated, less than 45 years old, and willing to spend more money while traveling (Bonn et al., 1999). Online agencies continue to increase their customer base and are shifting away from the travel supplier intermediary role by offering more vacation packages and by making site improvements to turn travel information seeking into travel bookings (Zellner, 2001). The most interesting development has been pure-play agencies' realization that first mover advantage is not critical in the online travel business, and in order to remain competitive, they will have to focus on customer segmentation and place new emphasis on customer service (Beirne, 2001).

The importance of customer service to the travel agent industry is not a new concept. Bitner 1990) uses travel agencies to illustrate the effects of physical surroundings and each employee-customer interaction on service quality. Using survey methodology, LeBlanc ) demonstrates the importance of corporate image; competitiveness (personalized service); and employee courtesy, responsiveness, competence, and accessibility as critical service quality factors. The 
SERVQUAL instrument has also been used in travel agencies as a diagnostic tool for improving customer service. (Ryan and Cliff find the SERVQUAL scale to be reliable, and discover that three of the five SERVQUAL dimensions (responsiveness, assurance and empathy) could be combined into a single dimension for reassurance. (Lam and Zhang, using SERVQUAL to assess the service quality of travel agents, indicate that factors for reliability, responsiveness and assurance play a crucial role in predicting customer satisfaction. A more direct connection between service quality factors and purchase intensions is discussed in a recent study showing attributes of agency reputation, word-of-mouth communication and staff attitude are most important to consumers when choosing a travel agency (Heung \& Chu, 2000). While service quality has been measured through gap analysis in various industries, little research has been done on the measurement of the Internet's impact on travel agencies' quality of service. The goal of this study is to provide new insight for service managers into factors influencing the quality of their services in light of the Internet's impact using the rapidly evolving travel agency industry as a case study.

\section{Methodology}

In this study, a qualitative exploratory research design was used because the literature on the travel agencies' internal organizational factors that contribute to service quality is not rich enough to suggest formal relationships among variables.

\subsection{Study Participants}

Interviews based on the Service Quality Model were used to conduct marketer's side (Gaps 1-4) analysis on eight (8) randomly selected brick-and-mortar and fourteen (14) multichannel agencies in a major metropolitan area in the East. The selection of local multichannel travel agencies was more complex. A multi-layered search on the American Society of Travel Agents (ASTA) and another online directory generated a list of twenty-two agencies for the area under study of which a geographic convenience sample of fourteen multichannel agencies was selected to allow for in-person interviews.

For both groups of agencies, the owners, senior managers or their travel agents were contacted by phone explaining the purpose of the study and requesting their cooperation in return for the results of the study. Approximately two weeks later, a personal interview was administered for each participating agency.

The interviews were conducted by the investigators of the study after ample time was devoted to ensure consistency in style and capturing data. To reduce the inter-rater reliability error, strict adherence to the questions was agreed upon with some freedom on changing the sequencing of them. The respondents were informed that the interview was being tape-recorded.

\subsection{Interview Questions: Quality Gaps $1-4$}

Constructs and related items on Gaps 1-4 were developed and adjusted to be compatible for the travel industry based on an extensive review of the literature on service quality. As result, the wording of some of the questions was changed to capture the unique nature of travel agencies and several additional variables were included to capture the impact of the Internet on the multichannel agencies' service delivery. As a result, the questionnaires' listed twenty-one and thirty-nine items to assess Gaps 1-4 for the brick-and-mortar and multichannel agencies, respectively. 


\section{Findings And Discussions}

\subsection{Quality Gaps 1-4}

Given the market's growing acceptance of electronic commerce, the brick-and-mortar travel agencies are especially vulnerable to losses in both market and customer share. At the same time computer-mediated environments are redefining customer perceptions and expectations of service quality, many of the brick-and-mortar agencies have not competitively positioned themselves to effectively communicate and transact business in this evolving industry.

\subsection{Gap 1: Management Perceptions of Customer Expectations}

The study revealed the brick-and-mortar travel agencies do make an effort to develop data banks, although the methodologies and the persons responsible for developing and maintaining customer accounts varied considerably. The majority of respondents indicated the travel agents bore the responsibility to manage files because of the necessity to build enduring customer-agent relationships. However, customer data files remain paper-based with content limited to data collected at the time of the service encounter and post-purchase inquires. The post-travel contact with the customer is generally no more than a perfunctory exercise or where in which as agencies mail comment cards requesting limited feedback. Only one agency conducts post-purchase telephone interviews to ascertain customer perceptions and satisfaction with the destinations, the properties and tour operators. Surprisingly, only two of the respondents indicated the agency compiled annual customer data; albeit no one acknowledged any data analyses that would identify market or product segments, reveal trends, or provide linkages to service quality issues.

The multichannel travel agencies do maintain customer data banks similar to those used by brick-and-mortar agencies. While two multichannel agencies do not keep customer files, the others either keep print files or use the airline's CRS system to access basic customer information. However, since $65-80 \%$ of the typical agency's business is generated by repeat customers, almost all respondents acknowledged the real value of customer data is based on the intangibles related to strong personal ties between customer and agent. Familiarization and the agent's memory are viewed as more significant factors in a service encounter.

Multichannel agencies' information sources and the process of collecting the data also mirror their brick-andmortar counterparts. Ten respondents indicated the mailing of welcome home letters with an enclosed comment card. The other four respondents preferred personal contact, most frequently through e-mail, as the method for collecting customer satisfaction/dissatisfaction data. However, half the respondents reported that the agency's Web site was to be used exclusively for promotional purposes rather than for communication or data gathering purposes.

The multichannel agencies' emphases on internal communication appear to be more driven by the customer. However, the use of Internet to learn about customer expectations is non-existent. None of the multichannel agencies require their agents to be Internet savvy nor do they provide incentives for employees to attend technology-training sessions.

\subsection{Gap 2: Service Quality Expectations}

Gap 2 deals with the organization's efforts to establish service standards based on what has been learned about customer expectations.

An assessment of the responses from brick-and-mortar agencies suggests they are more operations oriented than customer-driven. This operations orientation is most evident in the agencies' ad hoc approach to assessing their internal service quality standards. The responses varied from resolving daily service problems on an extempore basis to using an automated quality control package to verify the accuracy of ticket and customer documentation. One agency utilizes a full service assessment of random customers to identify problematic areas that are addressed internally through scheduled meetings. 
In contrast to their brick-and-mortar counterparts, the multichannel agencies' commitments to service quality are relatively more customer-driven. Eight of the fourteen multichannels are willing to serve as a liaison to voice customer complaints with wholesalers; albeit most acknowledge this is not a common occurrence due to longstanding supplieragency relationships. One respondent revealed, in the case of a serious breach in service quality, the agency strives to maintain goodwill by providing customers with a complimentary night at a hotel or a refund.

In all other respects, the multichannel agencies' general approach to assessing the internal service quality standards closely parallels the brick-and-mortars. Ten respondents indicated that standards are defined by company sales, profits, and the praises or complaints of repeat/loyal customers. One respondent, a franchise agency, stated random inquiries from a corporate "mystery caller" masquerading as a potential customer are initiated with results used to assess of agent's performance.

The use of the Internet by multichannel agencies to enhance service quality standards had mixed results. Half of the respondents do not use the Net to establish standards due, in part, to a lack of accessibility. In instances where accessibility does exist, five respondents indicated the use of the Internet is restricted to accessing information on product specials and destinations. Only two respondents indicate a true Gap 2 orientation by frequently searching the Internet for travel information to enhance customer personalization.

\subsection{Gap 3: The Actual Service Delivered}

Central to Gap 3 is management's commitment to an employee assessment program, employee training and the employees' perceptions of the quality of their work environment. The study revealed the latter is not an issue as the flat organizational structures promote teamwork and facilitate the flow of communication. (See Table 1)

Evaluation of employee skills and performance in brick-and-mortar agencies is significantly less formal than standard performance evaluation programs. Of the six respondents indicating the presence of a formal assessment program, half of the evaluations were actually conducted informally during company meetings. One respondent described employee assessment as no more than a trend line analysis of the agent's monthly sales production. The remaining two respondents did indicate the existence of agency programs that either annually assessed agent performances, (e.g., ticketing and calls taken) or periodically evaluated new agents during their first year. Notably absent from the agencies' responses were mentions of assessing employee interpersonal and behavioral skills.

The study did reveal a commitment to employee training in brick-and-mortar agencies, although the training appears focused on the agencies' operations. Five travel agencies do have an orientation program for new agents. Two respondents indicated their agencies favored a less formal mentoring program to orient new agents. The training for experienced brick-and-mortar agents appears to be more comprehensive. In fact, three respondents acknowledged inhouse, management-developed programs dedicated to training agents on recent innovations in network and software applications. At the other extreme, two agencies professed to address their training needs on-the-job during service encounters. Personal growth in interpersonal and behavioral areas is considered a function of mentoring, encouragement from management, or discussion at scheduled agency meetings.

The multichannel travel agencies are engaged in a multiplicity of agents' developmental programs. Six respondents indicated it was optional, albeit encouraged, for agents to attend professional meetings and maintain professional memberships. Four respondents revealed the FAM trips (familiarization programs provided by suppliers) were considered training programs, and the remaining four respondents stated that agency policy requires agents to attend wholesaler-sponsored seminars or enroll in courses as a vehicle for maintaining their credibility. Very little is done to develop recently hired agents in multichannel agencies. Commonly new agents are trained in using the reservation system, understanding airline and hotel codes, and developing competencies in travel products and world geography.

Nine multichannel respondents indicated agents are accessing product information via the Internet to enhance their skills in providing quality service to their customers. However, five respondents were fervent in their positions that the Internet will never replace the personalization and customization of services that an attentive agent provides his or her customers. 


\begin{tabular}{|c|c|c|}
\hline \multicolumn{3}{|c|}{ Table 1 - Quality Gaps $1-4$} \\
\hline Quality Gaps & Brick \& Mortar & Multichannel \\
\hline $\begin{array}{l}\text { Gap } 1 \\
\text { Does the agency maintain a customer } \\
\text { data bank? }\end{array}$ & $\begin{array}{l}5 \text { agencies indicate agents } \\
\text { manage customer files } \\
2 \text { agencies use the airline's CRS } \\
\text { system for client information } \\
1 \text { indicate a secretary manages } \\
\text { their files }\end{array}$ & $\begin{array}{l}6 \text { agencies indicate agents } \\
\text { manage customer files } \\
6 \text { agencies use the airline's CRS } \\
\text { system for client information } \\
2 \text { agencies do not keep customer } \\
\text { files }\end{array}$ \\
\hline $\begin{array}{l}\text { How is customer information } \\
\text { collected? }\end{array}$ & $\begin{array}{l}5 \text { agencies mail welcome home } \\
\text { letters with enclosed comment } \\
\text { card } \\
2 \text { agencies compile annual } \\
\text { customer data } \\
1 \text { agency conducts post-purchase } \\
\text { telephone interviews }\end{array}$ & $\begin{array}{l}10 \text { agencies mail welcome home } \\
\text { letters with enclosed comment } \\
\text { card } \\
4 \text { agencies preferred personal } \\
\text { contact by phone or e-mail }\end{array}$ \\
\hline $\begin{array}{l}\text { Gap } 2 \\
\text { Are service quality specifications } \\
\text { based on information collected from } \\
\text { customers? }\end{array}$ & $\begin{array}{l}8 \text { agencies indicate that } \\
\text { management has not set formal } \\
\text { quality standards for the } \\
\text { delivery of travel services }\end{array}$ & $\begin{array}{l}8 \text { agencies will voice customer } \\
\text { complaints with travel suppliers } \\
3 \text { agencies change vendors } \\
\text { due to customer complaints } \\
2 \text { agencies experience problems } \\
\text { infrequently } \\
1 \text { agency refunds customers } \\
\text { who file complaints }\end{array}$ \\
\hline $\begin{array}{l}\text { Have internal service quality } \\
\text { specifications been set? }\end{array}$ & $\begin{array}{l}6 \text { agencies have a policy of giving } \\
\text { complimentary gifts to V.I.P. } \\
\text { customers } \\
1 \text { agency relies on experienced } \\
\text { agents' own perceptions of } \\
\text { service quality }\end{array}$ & $\begin{array}{l}10 \text { agencies define standards } \\
\text { through financial performance } \\
\text { and customer comments } \\
1 \text { agency uses a mystery caller } \\
\text { to assess agent performance }\end{array}$ \\
\hline $\begin{array}{l}\text { Gap } 3 \\
\text { How are employee skills evaluated? }\end{array}$ & $\begin{array}{l}6 \text { agencies have a formal agent } \\
\text { assessment program } \\
3 \text { agencies use annual or monthly } \\
\text { quantitative assessments of } \\
\text { agents' sales }\end{array}$ & $\begin{array}{l}5 \text { agencies provide perks like free } \\
\text { trips to high performing agents } \\
4 \text { use money \& raises as incentive } \\
2 \text { agencies provide non-monetary } \\
\text { awards } \\
1 \text { agency provides no rewards for } \\
\text { performance }\end{array}$ \\
\hline How are employees trained? & $\begin{array}{l}7 \text { agencies have an orientation } \\
\text { or mentoring program for new } \\
\text { agents } \\
4 \text { agencies require experienced } \\
\text { agents to attend formal training } \\
2 \text { agencies provide on-the-job } \\
\text { training }\end{array}$ & $\begin{array}{l}6 \text { agencies provide optional but } \\
\text { recommended training sessions } \\
4 \text { agencies use supplier familiarity } \\
\text { trips (FAM) for training } \\
1 \text { agency requires under- } \\
\text { performing agents to attend } \\
\text { training }\end{array}$ \\
\hline $\begin{array}{l}\text { Gap } 4 \\
\text { Do employees communicate } \\
\text { horizontally within the agency? }\end{array}$ & $\begin{array}{l}3 \text { agencies have managers who } \\
\text { encourage employees to share } \\
\text { customer profiles with each } \\
\text { other }\end{array}$ & $\begin{array}{l}14 \text { agencies receive faxes from } \\
\text { travel wholesalers } \\
5 \text { agencies review these faxes } \\
\text { daily to better serve customers } \\
2 \text { agencies review promotional } \\
\text { e-mail from travel wholesalers }\end{array}$ \\
\hline $\begin{array}{l}\text { How does the agency communicate } \\
\text { externally to customers? }\end{array}$ & $\begin{array}{l}5 \text { agencies have either a formal or } \\
\text { an informal budgeting process } \\
\text { for newspaper \& direct mail } \\
\text { advertising expenditures } \\
2 \text { agencies depend on word-of- } \\
\text { mouth referral }\end{array}$ & $\begin{array}{l}11 \text { agencies use print media-most } \\
\text { frequently newspapers } \\
5 \text { agencies use direct mailings } \\
4 \text { agencies use word-of-mouth } \\
\text { contact } \\
3 \text { agencies advertise online }\end{array}$ \\
\hline
\end{tabular}




\begin{tabular}{|c|c|}
\hline \multicolumn{2}{|c|}{ Table 2 - Internet and Multichannel Agencies } \\
\hline Quality Gaps & Multichannel \\
\hline $\begin{array}{l}\text { Gap } 1 \\
\text { Is the Internet used to gather information? }\end{array}$ & $\begin{array}{l}14 \text { agencies do not require agents to be Internet savvy } \\
2 \text { respondents had either personal home pages or e- } \\
\text { mail accounts }\end{array}$ \\
\hline $\begin{array}{l}\text { Gap } 2 \\
\text { Is the Internet used to enhance or develop internal service } \\
\text { quality standards? }\end{array}$ & $\begin{array}{l}7 \text { agencies do not use the Internet to establish service } \\
\text { standards } \\
5 \text { agencies restrict agents to using the Internet only for } \\
\text { travel product information } \\
2 \text { agencies use Internet to enhance service quality }\end{array}$ \\
\hline $\begin{array}{l}\text { Gap } 3 \\
\text { Are employees using the Internet for professional } \\
\text { development? }\end{array}$ & $\begin{array}{l}9 \text { agencies use the Internet to develop their professional } \\
\text { travel knowledge } \\
5 \text { agencies do not view the the Internet as important in } \\
\text { developing their skills }\end{array}$ \\
\hline $\begin{array}{l}\text { Gap } 4 \\
\text { Is the Internet a viable promotional medium to reach } \\
\text { customers? }\end{array}$ & $\begin{array}{l}7 \text { agencies view the Internet as helpful in communicating } \\
\text { with customers } \\
7 \text { agencies do not see the benefit of the Internet as a } \\
\text { promotional medium }\end{array}$ \\
\hline How is the agency's Web presence maintained? & $\begin{array}{l}6 \text { agencies do not know who maintains their Web page/site } \\
5 \text { agencies have Web sites maintained by travel agency } \\
\text { employees or headquarters } \\
1 \text { agency out sources site maintenance to a Web designer }\end{array}$ \\
\hline
\end{tabular}

\subsection{Gap 4: Communicating About the Service to Customers}

Gap 4 is concerned with the organization's need to promote horizontal communication between employees and with external communication to customers. Only three respondents indicated management's encouragement for agents to share customer profiles with each other. Despite the finding, many respondents felt that peer communication is openly practiced due to the sheer volume of service encounters, especially during seasonal periods, which foster teamwork.

The propensity to promote services varies substantially across brick-and mortar respondents. Only three respondents indicated their agencies had a formal budgeting process to determine the allocation of funds to newsprint and direct-mailing media. For most respondents, the process of budgeting promotional dollars is even less formal, driven by seasonal demand and type of customer. One respondent indicated differences in the travel destinations (i.e., international vs. domestic) and modes of travel (airplane vs. cruise) are reflected in the budget and media selection. Leisure travelers are more actively targeted than business travelers and advertisements by brick-and-mortar agencies are exclusively presented through print-media, although two smaller agencies still depend on word-of-mouth referrals.

The multichannel travel agencies' sharing of information has not only an internal presence, but also an external presence through relationships with external stakeholders. For example, every respondent indicated they receive between 50-250 daily fax transmissions from travel wholesalers promoting travel packages and specials, and many respondents acknowledged sharing wholesaler information horizontally between agents on a daily basis to better serve their customers. Furthermore, two respondents revealed the use of e-mail messages sent by wholesalers were used as an additional source of shared information.

An assessment of the responses from multichannel agencies indicated that newspapers, direct mailings and brochures were the more commonly used print media with online advertising and the yellow pages used to a lesser extent. The sharing of information between agencies and wholesalers is demonstrated through cooperative advertising 
partnerships with cruise lines and other travel suppliers (i.e., airlines and hotel chains). The respondents were equally divided on their opinions regarding the Internet's effectiveness as a communication medium; a perception that may be associated with an agent's belief that the emerging technology is no substitute for personally-developed customer relationships.

\section{Conclusions}

Adopting an orientation to deliver superior quality service requires organizations to learn extensively about and consistently conform to customer expectations. As stated by Zeithaml et al. (1988) "the size of Gap 1 should depend greatly on the amount of market research conducted because it is a key variable for understanding consumer expectations and perceptions of service". It was further stated the degree to which the research focuses on service quality issues is an additional research-related variable associated with the Gap 1 analysis. Unfortunately, due to either limited resources or lack of relevant skills, the travel agencies rarely conduct research into customers' expectations. Instead, what information that is collected on customers is based on word-of-mouth communication, personal needs, past experience and post-travel feedback.

Since Gaps 2-4 are inextricably linked to Gap 1, logic dictates that any problems associated with the first gap will be exacerbated as the organization progresses through the subsequent steps. For example, due to Gap 1 problems, the travel agencies have not established well-defined service quality specifications that are based on customer expectations (Gap 2). In cases when customers pose questions relative to the service quality standards, a Gap 3 problem frequently arises because the travel agent's advice on destination choice is not comprehensive. The gap is accentuated by the agencies' shortsightedness in failing to mandate their agents attend development programs. Because customers place a premium on the agent's communication skills, travel agencies have made themselves susceptible to Gap 4 problems by not placing an equal importance on the development of agents' interpersonal skills.

Also in question is multichannel agencies commitment to using the Internet in the marketing research arena. The Internet has shown great potentials for new product development, communication and user interaction. However, even at a basic level, none of the multichannel agencies' Web sites allow customers to book online; thus negating the agent's ability to spend more time providing personalized information to customers.

If multichannel agencies could bring the service quality of their e-presence up to the quality of the pure-plays, the multichannel agencies could offer both the convenience and control of the pure-plays' services with the advantage of providing personalized, customized information. Even small multichannel agencies could specialize in certain types of travel that are not targeted by the large pure-play sites. While the hi-tech, low-touch nature of the pure-plays will appeal to those in need of general travel assistance, the hi-tech hi-touch aspects of the multichannel agencies have the potential to offer both the convenience and personalized attention that consumers want.

While technology can assist companies realize this potential, the most technologically advanced system will not operate in a vacuum. Trained, responsive back-end customer service representatives are the keys to the success of online service providers.

In sum, the Internet offers many opportunities to improve the quality of service. Through use of technology combined with the human touch, the size of the five quality gaps can be substantially reduced. Gap 1 can be greatly reduced by using technology to gather data on consumers both directly through online surveys or telephone interactions and more surreptitiously through transaction logs. Database technology can be used to set strict service quality standards for response time, delivery of services and employee conduct. Consequently, setting the proper standards to meet customers' expectations and ensuring that those standards are met would go far in reducing Gaps 2 and 3.

Organizations can provide customized information based on individuals' needs and remove the responsibilities from their customers. Multichannel firms are able to involve customers in the purchasing process by expecting them to handle the pre- and post- purchase activities without the human touch of a knowledgeable intermediary. However, 
multichannel companies must dramatically improve the quality of their online presence in order to reflect the professional quality of the high-touch, personalized services they can offer consumers.

The time "to do business as usual" is gone and remaining reactive is a dangerous position. Thus, the future belongs to those multichannel agencies that offer convenient specialized, personalized, customized and timely service. It is then that they will be on their way to mastering the art of being "Hi-tech" and "Hi-touch" agencies.

\section{Limitations of the Study}

This is an exploratory study and therefore possesses all the limitations associated with such research. The goal of this qualitative study was to provide new insight into factors influencing the quality of services in light of the Internet's impact using the rapidly evolving travel agency industry as a case study. As such, caution should be exercised in generalizing the findings of this study to other industries or other regions. Furthermore, even though appropriate steps were taken to reduce the inter-interviewer reliability, future studies could benefit from a more rigorous set of measures.

\section{Suggestions for Future Research}

Future research should expand the application of the Service Quality Model for the study of brick-and-mortar and multichannel travel agencies to include analysis of Gap 5: the expected service - perceived service gap from the consumers' perspective. This comparative study of how quality of service is perceived by both brick-and-mortar and multichannel travel consumers would illustrate the evolving nature of service quality in the electronic commerce environment. In addition, Gaps 1-4 analysis of pure-play travel agencies would provide valuable new insight into the internal service quality factors of e-Business firms. In addition, future research must identify variables to ensure a positive relationship between profits and service quality and affirm that there exists a relationship between the customers' favorable behavioral intentions and actual purchase behaviors given the quality of the service. Application of the Service Quality Model across a wide variety of online service industries is the authors' long-term research plan.

\section{References}

1. Anckar, Bill and Pirkko Walden, "Destination Maui? An exploratory assessment of the efficacy of self-booking in travel," Electronic Markets, Vol. 10, No. 2, pp. 110-119, 2000.

2. Babakus, Emin and W. Glynn Mangold, "Adapting the SERVQUAL scale to hospital services: an empirical investigation," Health Services Research, Vol. 26, No. 6, pp. 767-787, 1992.

3. $\quad$ Beirne, Mike, "Upping the ante," Brandweek, Vol. 42, No. 33, pp. 30-38, 2001.

4. Bell, H. and N. K. H. Tang, "The effectiveness of commercial Internet web sites: a user's perspective," Internet Research, Vol. 8, No. 3, pp. 219-228, 1998.

5. Bitner, Mary Jo, "Evaluating service encounters: The effects of physical surroundings and employee responses," Journal of Marketing, Vol. 54, pp. 69-82., 1990.

6. Bitner, Mary Jo, Stephen W. Brown, and Matthew L. Meuter, "Technology infusion in service encounters," Journal of the Academy of Marketing Science, Vol. 28, No. 1, pp. 138-149, 2000.

7. Bonn, Mark A., H. Leslie Furr, and Alex M. Susskind, "Predicting a behavioral profile for pleasure travelers on the basis of internet use segmentation," Journal of Travel Research, Vol. 37, No. 4, pp. 333-340, 1999.

8. Carman, James M., "Consumer perceptions of service quality: an assessment of the SERVQUAL dimensions," Journal of Retailing, Vol. 66, No. 1, pp. 33-55, 1990.

9. Cronin Jr., J. Joseph and Steven A. Taylor, "Measuring service quality: a reexamination and extension," Journal of Marketing, Vol. 56, No. 3, pp. 55+, 1992.

10. Dedhia, Navin S., "E-commerce quality," Total Quality Management, Vol. 12, No. 3, pp. 397-402, 2001.

11. Glab, Jim, "Online travel trends," Travel Weekly, Vol. 60, No. 77, pp. 59-61, 2001.

12. Grapentine, Terry, "The history and future of service quality assessment," Marketing Research, Vol. 10, No. 4, pp. 4+, 1999.

13. Gummesson, Evert, "Truth and myths in service quality," Journal for Quality and Participation, Vol. 18, No. 6, pp. 18-23, 1995. 
14. Heung, Vincent C. S. and Raymond Chu, "Important factors affecting Hong Kong consumers' choice of a travel agency for all-inclusive tours," Journal of Travel Research, Vol. 39, No. 1, pp. 52-59, 2000.

15. Kaynama, Shohreh A. and Christine I. Black, "A proposal to assess the service quality of online travel agencies: an exploratory study," Journal of Professional Services Marketing, Vol. 21, No. 1, pp. 63-88, 2000.

16. Keeney, Ralph, "Value of internet commerce to the customer," Management Science, Vol. 45, No. 4, pp. 533542, 1999.

17. Kessler, Scott H., "Computers: consumer services and the Internet," In Industry Surveys, Standard \& Poor's , New York, 2001.

18. Lam, Terry and Hanqin Qiu Zhang, "Service quality of travel agents: the case of travel agents in Hong Kong," Tourism Management, Vol. 20, No. 3, pp. 341-349, 1999.

19. LeBlanc, Gaston, "Factors affecting customer evaluation of service quality in travel agencies: an investigation of customer perceptions," Journal of Travel Research, Vol. 30, No. 4, pp. 10-16, 1992.

20. Lewis, Ira, Janjaap Semeijn, and Talalayevsky Alexander, "The impact of information technology on travel agents," Transportation Journal, Vol. 37, No. 4, pp. 20-25, 1998.

21. Lynch, Patrick D., "The global Internet shopper: evidence from shopping tasks in twelve countries," Journal of Advertising Research, Vol. 41, No. 3, pp. 15-23, 2001.

22. Parasuraman, A., Grewal, and Dhruv, "The impact of technology on the quality-value-loyalty chain: a research agenda," Journal of the Academy of Marketing Science, Vol. 28, No. 1, pp. 168-174, 2000.

23. Parasuraman, A., V. Zeithaml, and L. Berry, "Alternative scales for measuring service quality: a comparative assessment based on psychometric and diagnostic criteria," Journal of Retailing , Vol. 70, No. 3, pp. 201-230, 1994.

24. Parasuraman, A., Valarie A. Zeithaml, and Leonard L. Berry, "A conceptual model of service quality and its implications for future research," Journal of Marketing, Vol. 49, No. 4, pp. 41-50, 1985.

25. Parasuraman, A., Valarie A. Zeithaml, and Leonard L. Berry, "SERVQUAL: a multiple-item scale for measuring customer perceptions of service quality," Journal of Retailing, Vol. 64, No. 1, pp. 12-40, 1988.

26. Reichheld, F. F., "Learning from customer defections," Harvard Business Review, Vol. 74, pp. 56-69, 1996.

27. Ryan, Chris and Andrew Cliff, "Do travel agencies measure up to customer expectation? An empirical investigation of travel agencies' service quality as measured by SERVQUAL," Journal of Travel \& Tourism Marketing, Vol. 6, No. 2, pp. 1-31, 1997.

28. Saunders, Gary, "Commercial use of the Internet: some pros and cons," Journal of Applied Business Research, Vol. 16, No. 1, pp. 1+, 2000.

29. Wang, Shouhong, "Managing the organizational aspects of electronic commerce," Human Systems Management, Vol. 19, No. 1, pp. 49-59, 2000.

30. Zeithaml, Valarie A., "Service quality, profitability, and the economic worth of customers," Journal of the Academy of Marketing Science, Vol. 28, No. 1, pp. 67-85, 2000.

31. Zeithaml, Valarie A., Leonard L. Berry, and A. Parasuraman, "Communication and control processes in the delivery of services," Journal of Marketing, Vol. 52, No. 2, pp. 35-48, 1988.

32. Zeithaml, Valarie A., Leonard L. Berry, and A. Parasuraman, "The behavioral consequences of service quality," Journal of Marketing, Vol. 60, pp. 31-46, 1996.

33. Zeithaml, Valarie A., A. Parasuraman, and Arvind Malhotra, A Conceptual Framework For Understanding EService Quality, Marketing Science Institute, Cambridge, MA, 2000.

34. Zellner, Wendy, "Where the net delivers: travel," Business Week, No. 3736, pp. 142-144, 2001. 
Notes 